\title{
A raposa de cima e a raposa de baixo em português
}

Ligia Karina Martins de Andrade*

Arguedas, José María. A raposa de cima e a raposa de baixo. Trad. Rômulo Monte Alto. Belo Horizonte: EDITORAufmg, 2016. 305p. ISBN: 978-85-423-0138-0

\footnotetext{
${ }^{*}$ Doutora e Mestre em Lingua Espanhola e Literaturas Espanhola e Hispano-Americana pela USP, professora de Lingua Espanola Adicional na UNILA (Universidade Federal da Integração LatinoAmericana), email: ligia.andrade@unila.edu.br
} 
O público brasileiro já pode contar, desde 2016, com a tradução em língua portuguesa da obra póstuma do escritor e antropólogo peruano José María Arguedas (1911-1969). A raposa de cima e a raposa de baixo, publicada em 1971, é considerada uma das obras centrais da literatura latino-americana, devido ao seu caráter experimental e inovador em relação à linguagem e às línguas que a compõem.

Esta tradução, que ora se apresenta, integra a coleção Fora de Série, sob os cuidados da Editora da Universidade Federal de Minas Gerais, Editoraufmg. Basta mencionar que esta coleção, na atualidade, se ocupa de uma missão central como difusora da cultura latino-americana no Brasil e responde à tradução de obras fundamentais da Literatura e da Crítica Literária Latinoamericanas contemporâneas, levando ao leitor -especializado ou não- uma sorte de obras pioneiras em língua portuguesa. No entanto, a tradução de El zorro de arriba y el zorro de abajo, a partir da edição original de Eve-Marie Fell, atinge um objetivo bem mais amplo ao presentear o público leitor com a obra ficcional, apontada pela crítica literária latino-americana, como uma obra considerada chave e que, poderíamos utilizar as palavras do eu autobiográfico dos diários, “fecha um ciclo para abrir outro ciclo" (Arguedas 2016: 282) no Peru e na vida do autor. O crítico Echevarría (2000) afirmou que tal obra, ao entrar no arquivo literário latino-americano, abre uma fissura ou rasura no denominado arquivo do Continente, devido ao fato de questionar as suas obras mais consagradas e exitosas, visto que seu caráter de ruptura e inovação abre o fracasso do projeto literário de registro do Outro nos moldes do Ocidente e da legitimidade de falar pelo Outro a partir deste cânone.

A importância desta tradução deve-se ainda à "personalidade literária e cultural", como senhalou Cornejo Polar, protagonizada por José María Arguedas e sua centralidade para a cultura peruana, sobretudo a região andina, o qual deixou como legado uma rica e extensa obra, composta por aproximadamente quatro tomos de ficção e seis tomos de estudos antropológicos e etnográficos sobre o país, como nos aponta a introdução de Rômulo Monte Alto. Nela, o 
crítico, professor e tradutor da UFMG traz importantes dados autobiográficos de José María para o público que queira conhecer a obra, e elenca ainda uma original autobiografia do autor a partir da seleção de dados pouco divulgados em geral e que fazem parte de uma minuciosa e profunda pesquisa do tradutor, cujo interesse também recai sobre o público especializado.

Cabe destacar, ainda, que Rômulo Monte Alto foi um dos pioneiros no estudo da literatura da comarca andina no Brasil e o criador e coordenador da atual "Rede de Estudos Andinos", composta por pesquisadores e professores de diversas instituições de ensino superior no país. Ele promoveu o primeiro "Colóquio Internacional A herança de Arguedas aos quarenta anos de sua ausência", de 16 a 19 de Juno de 2010, na cidade de Belo Horizonte, na UFMG. A importância deste evento residiu na reunião de vários estudiosos do tema, entre eles: Zélia Bora, Silvina Carrizo, Marcos P. Natali, Ligia K. M. de Andrade, entre outros pesquisadores e professores, e com a presença de dois destacados escritores peruanos, que se intitulam herdeiros da tradição arguediana, entre eles: Oscar Lucio Colchado e Enrique Rosas Paraviccino. Este evento congregou as pesquisas que estavam sendo desenvolvidas ao redor da obra arguediana e da literatura andina e peruana no Brasil, apontando a necessidade de criação e expansão desta rede de estudos.

Daí, observa-se que o resultado desta tradução em si advém de inúmeros estudos realizados pelo grupo coordenado pelo referido tradutor, e da tarefa/renúncia benjaminiana empreendida por ele, para trazer à luz a tradução ao português de uma, dentre as obras mais complexas em termos tradutológicos, da literatura peruana. Neste sentido, esta tradução será certamente fonte de vários estudos futuros, lançando os tradutores na selva idiomática e no jogo das línguas e sua tradução transcriadora.

Esta complexidade reside no fato de José María ter sido, além de escritor e antropólogo, um exímio tradutor de importantes obras em quéchua, tais como: poemas, lendas, rituais, etc e o reconhecido texto Dioses y Hombres de Huarochirí, cuja tradução foi realizada nos tumultuados anos em que redigia sua 
obra póstuma. A tarefa/renúncia de Arguedas como escritor e tradutor exibe uma série de concepções da tradução e das teorias tradutológicas em suas obras, que se superpõem em diversos momentos de sua produção artística e antropológica até culminar com sua fórmula enunciada em $A$ raposa de cima e a raposa de baixo, nas páginas iniciais do "Primeiro diário" de que o encontro com a jovem prostitura recuperou o vínculo quebrado entre corpo e alma e que: "quando este vínculo era intenso, eu conseguia transmitir à palavra a matéria das coisas" (31). Na obra em questão, o autor recorre à autobiografia, um gênero de invenção e transcriação do passado desde uma perspectiva multitemporal por excelência, e o entrelaça à parte ficcional, numa permanente autotradução linguística e cultural do universo andino, quechua e indígena a outro castelhano, ocidental e desencantado, esgarçando o fio do discurso secular castelhano com a oralidade e vivacidade próprias de falares regionais e variantes das personagens. Aliàs, é necessário se deter na performance em língua portuguesa destas personagens, cujos destinos estão traçados pelas regras das incertezas do mercado e da produção capitalista na caótica cidade de Chimbote e a falácia das línguas precariamente dominadas e cheias de desejo e luxúria. Há inúmeros examples deltas variants andinas traduzidas cuidadosamente à variante do português brasileiro com um toque rosiano: os pescadores, as prostituras, Don Esteban, o louco Moncada, o padre Cardozo com seu castelhano com sotaque inglês, dentre outros. Citemos um exemplo desta Babel linguística presente num fragmento de fala do padre estadunidense Cardoso traduzido numa variante do português brasileiro:

(...)Essas são as palavras mancas. Vou dizer, dom Cecílio, com sua dispensa, as únicas, porém, fodidas palavras que lembro para expressar experiências que o castelhano e o inglês, naturalmente, não conseguem expressar bem, acho, que porque nós já não gozamos delas e nem as sofremos. Alguma coisa aprendi do quéchua. Poucas, porém

TradTerm, São Paulo, v. 30, Novembro/2017, p. 193-198 www.usp.br/tradterm 
boas palavras e frases; pouquíssimas canções. (Arguedas 2016: 254)

É nesta direção que a tradução procurou tanger à obra, no sentido benjaminiano de fazer ecoar todas as línguas num ponto do sentido, e adotou critérios muito afinados com o texto inicial no que toca ao processo de traducibilidade presente na obra original, uma vez que o tecido textual se compõe da tradução do quechua ao espanhol e de uma aproximação que afeta e altera os idiomas num processo de contato e confronto, o que se reflete na mencionada fala "aluvional" das personagens que povoam o cenário de Chimbote e ressignificam sua identidade linguística e cultural na desordenada ocupação da cidade litorânea do Peru, e sua transformação por meio do Capital e da alteração nas relações sociais. Estas estratégias de tradução entre quéchua e castelhano podem ser cotejadas com a edição original, que igualmente traz ao final da obra um glossário elaborado pelos editores e mantido pelo tradutor. Há ainda exemplos de termos no original em quéchua com a respectiva tradução ao castelhano no interior do texto arguediano, a modo de nota de pé de página, que se mantém na tradução ao português e ainda vocábulos sem tradução, tornando espessa e impenetrável a tarefa de compreensão total do sentido pelo leitor, o que revela a tensão entre as línguas no texto e a indagação de que neste caminho, entre o início da tradução e o final da mesma, algo como alerta George Mounin não se deixa traduzir, remetendo ao Outro, ao estranho e à impossibilidade de traduzir. Parece que o tradutor vivenciou estas estratégias e as angústias do percurso da tradução por meio das escolhas traçadas do início ao final de sua tarefa, mantendo coerentes estas possibilidades de traducibilidade de maneira bem definidas e seguindo-as, legando ao público o acesso a uma obra de grande beleza, contraste e representativa de nossa literatura latinoamericana. 


\section{Referências bibliográficas}

Arguedas, José María. El zorro de arriba y el zorro de abajo. 2.ed., Ed. Crít. EveMarie Fell. Madrid: ALLCA XX, 1996.

Cornejo Polar, A. O condor voa: literatura e cultura latino-americanas. Trad. Ilka V. Carvalho. Belo Horizonte: Editora UFMG, 2000.

Echevarría, R. G. Trad. Virgínia A. Muñoz. "La novela como mito y archivo: ruinas y reliquias de Tlön" in: Mito y Archivo. Una teoría de la narrativa latinoamericana. Mexico: FCE, 2000.

Mounin, Georges. Os problemas teóricos da traduçāo. Trad. Heloysa de Lima Dantas. Sao Paulo: Editora Cultrix, 1975. 